\title{
ANALISIS PENGGUNAAN DINDING KANTILEVER UNTUK MENGATASI KASUS KERUNTUHAN LERENG DI KOTA MUARA TEWEH KABUPATEN BARITO UTARA
}

\author{
RM Malawy ${ }^{1}$, S Gandi ${ }^{2}$ dan F Sarie ${ }^{3}$ \\ ${ }^{123}$ Program Studi Teknik Sipil, Fakultas Teknik, Universitas Palangka Raya \\ E-mail: rizqanmaulana93@gmail.com ${ }^{1}$, suradjigandi_ir@jts.upr.ac.id ${ }^{2}$,dan \\ fatmasarie@jts.upr.ac.id ${ }^{3} /$ HP.+6285391410942 ${ }^{1}$
}

\begin{abstract}
ABSTRAK
Perkembangan transportasi di Indonesia yang semakin meningkat menyebabkan naiknya kebutuhan lahan untuk penggunaan jalan. Transportasi memegang peranan yang penting karena komunikasi tidak dapat dijalankan tanpa ada hubungan yang cukup baik didalam wilayah ataupun antar wilayah. Hal ini mendorong manusia untuk memanfaatkan setiap lahan yang ada sebaik mungkin, salah satunya di kawasan perbukitan dan berlereng yang topografinya cenderung beragam. Namun untuk mewujudkan transportasi yang aman, nyaman, dan memiliki konstruksi yang awet pada daerah lereng, diperlukan sebuah analisis terhadap tingkat keamanan lereng dalam perencanaannya. Penelitian yang dilakukan meliputi survei lokasi, pengambilan sampel tanah, dan pemboran tanah. Jenis sampel yang akan digunakan ada dua jenis yaitu sampel tanah asli atau tidak terganggu dan sampel tanah yang terganggu. Dari pengujian yang dilakukan dengan menggunakan metode sistem klasifikasi AASTHO dan USCS diketahui tanah di Kota Muara Teweh Kabupaten Barito Utara adalah tanah lanau berpasir dengan plastisitas tinggi. Hasil analisis perhitungan angka keamanan lereng menggunakan metode fellenius untuk kondisi lereng tanpa terendam air adalah 1,5, Angka keamanan untuk kondisi lereng terendam air adalah 0,9, Hasil analisis dinding penahan tanah tipe Kantilever untuk stabilitas terhadap gaya guling adalah 4,54; untuk stabilitas terhadap gaya geser adalah 1,95; untuk stabilitas terhadap daya dukung tanah adalah $651,034 \mathrm{kN} / \mathrm{m}^{2}$. Hasil perhitungan analisis dinding penahan tanah tipe Kantilever menyatakan aman terhadap gaya guling dan geser.
\end{abstract}

Kata kunci: dinding penahan tanah, metode fellenius, stabilitas

\begin{abstract}
Development of transportation that increase in Indonesia lead an increasing of land needed for road uses. Transportation plays an important role because the communication cannot carrie out good relations in region or between regions. This encourages people to take advantage of every available land as well as possible, one of which is in hilly and sloping areas whose topography tends to be diverse. However, an analysis of the level of slope safety is needed in its planning to realize the safe, comfortable, and durable construction on slopes. The research is about site survey, sampling of soil, and soil drilling. There are use two kind of sample, that is namely of originaly soil or undisturbed soil samples and disturbed soil samples. Based on the AASTHO and USCS classification system method test,
\end{abstract}


there is known that the soil in Muara Teweh City, North Barito Regency is a sandy silt soil with low plasticity. Results of the calculation analysis, safety number by the fellenius method for slope conditions without being submerged in water is 1.5 . Safety score for the submerged slope is 0.9 . Results of cantilevertype ground retaining wall analysis for stability to rolling force is 4.54; for stability to the sliding force is 1.95 ; for stability to soil carrying capacity is $651,034 \mathrm{kN} / \mathrm{m}^{2}$. Results of cantilever-type ground retaining wall calculation of analysis is stated safe to the rolling force, and shear.

\section{Keywords: retaining wall, fellenius method, stability}

\section{PENDAHULUAN}

\section{Latar Belakang}

Perkembangan transportasi di Indonesia yang semakin meningkat menyebabkan naiknya kebutuhan lahan untuk penggunaan jalan. Transportasi memegang peranan yang penting karena komunikasi tidak dapat dijalankan tanpa ada hubungan yang cukup baik didalam wilayah ataupun antar wilayah (Husmann, 1987). Hal ini mendorong manusia untuk memanfaatkan setiap lahan yang ada sebaik mungkin, salah satunya di kawasan perbukitan dan berlereng yang topografinya cenderung beragam. Namun untuk mewujudkan transportasi yang aman, nyaman, dan memiliki konstruksi yang awet pada daerah lereng, diperlukan sebuah analisis terhadap tingkat keamanan lereng dalam perencanaannya.Tingkat keamanan suatu lereng dipengaruhi oleh beberapa faktor, diantaranya adalah faktor kemiringan dan beban yang bekerja diatasnya. Kondisi lereng dengan beban yang besar dan kemiringan yang curam dapat menyebabkan terjadinya kelongsoran. Pengaruh hujan deras yang mengguyur sebagian besar wilayah Kota Muara Teweh, Kabupaten Barito Utara mengakibatkan kelongsoran dan pengikisan sebagian bahu jalan Jembatan Sei Bengaris. Hal ini tentunya sangat membahayakan bangunan dan pengguna jalan di sekitar lereng sehingga diperlukan solusi yang bisa menjadi alternatif untuk menjadikan lereng tersebut aman dari bahaya longsor. Salah satunya adalah dengan membangun konstruksi perkuatan pada lereng tersebut.

\section{Tujuan Penelitian}

Dalam penelitian ini bertujuan untuk mengetahui sifat fisik dan mekanik tanah pada daerah longsoran di ruas jalan Kota Muara Teweh, mengetahui stabilitas lereng pada daerah longsoran, dan mengetahui stabilitas dinding penahan tanah pada daerah longsoran.

\section{METODE PENELITIAN}

\section{Lokasi Penelitian}

Lokasi penelitian adalah tempat atau wilayah penelitian dilakukan. Lokasi penelitian yang menjadi acuan yaitu Kota Muara Teweh Kabupaten Barito Utara Provinsi Kalimantan Tengah.

\section{Metode Pengambilan Data}

Pengumpulan data sifat fisik berdasarkan data sekunder hasil pengujian 
laboratorium yang dilakukan oleh PT. CEMARA GEO ENGINEERING pada proyek Penanganan Longsor Bahu Jalan Jembatan Sei Bengaris.

\section{HASIL DAN PEMBAHASAN}

Tabel 1 Hasil pemeriksaan sifat fisik tanah

\begin{tabular}{|l|l|c|}
\hline No. & \multicolumn{1}{|c|}{ Jenis Pemeriksaan } & $\begin{array}{c}\text { Hasil Pengujian } \\
\text { Rata - rata }\end{array}$ \\
\hline 1. & Kadar Air (Water Content) $\%$ & 27,50 \\
\hline 2. & Berat Isi (Denisty Test) $\mathrm{g} / \mathrm{cm}^{3}$ & 1,70 \\
\hline & a. Berat isi tanah basah Rata-rata & 1,34 \\
\hline & b. Berat isi tanah kering Rata-rata & 2,342 \\
\hline 3. & Berat Jenis (Specific Gravity) & \\
\hline 4. & Batas-Batas Atterberg (\%) & 51,68 \\
\hline & a. Batas Cair (Liquid Limit) & 32,41 \\
\hline & b. Batas Plastis (Plastic Limit) & 19,27 \\
\hline & c. Indeks Plastisitas (Plastic Indeks) & \\
\hline 5. & Analisis Saringan & 42,10 \\
\hline & a. Persentase Berat Tertahan (\%) & 16,65 \\
\hline & b. Persentase Lolos (\%) & \\
\hline
\end{tabular}

Sumber: Hasil Pengujian Laboratorium PT. CEMARA GEO ENGINEERING (2021)

\section{Analisis Metode Klasifikasi Tanah}

\section{Sistem Klasifikasi AASHTO}

Klasifikasi tanah berdasarkan sistem AASHTO mengikuti prosedur sebagai berikut:

1) Dari hasil pemeriksaan analisis saringan, persentase material lolos saringan No. $200(0,075 \mathrm{~mm})$ adalah $16,65 \%<35 \%$.

2) Pemeriksaan batas-batas Atterberg didapat nilai batas cair (LL) rata-rata $=$ $51,68 \%>40 \%$ dan indeks plastisitas $(\mathrm{PI})$ rata-rata $=19,27 \%>11 \%$ maka tanah tersebut termasuk kelompok A-2-7. (Gambar 1) 


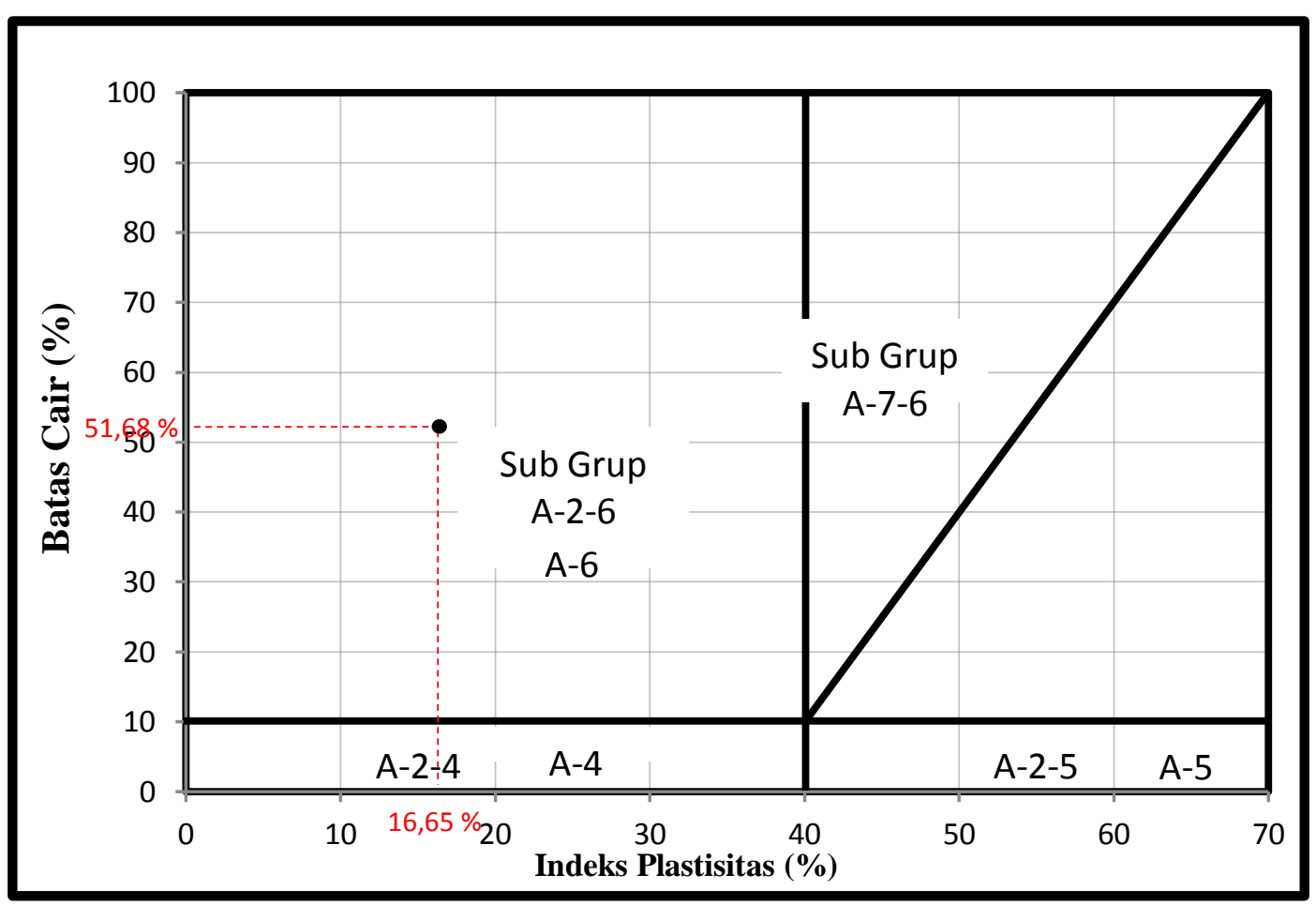

Gambar 1. Grafik Klasifikasi Tanah Sistem Klasifikasi AASHTO

Kelompok A-2-7 adalah kelompok kerikil dan pasir yang berlanau atau berlempung.

\section{Sistem Klasifikasi USCS}

Klasifikasi tanah berdasarkan sistem USCS mengikuti prosedur sebagai berikut:

1) Dari hasil pemeriksaan analisis saringan, persentase material lolos saringan No.200 $(0,0075) \mathrm{mm})$ rata-rata $=16,65 \%<50 \%$, maka tanah tersebut termasuk tanah berbutir halus.

2) Dari hasil pemeriksaan batas-batas atterberg, didapat nilai batas cair (LL) rata-rata $=51,68 \%>50 \%$, maka tanah tersebut termasuk kelompok $\mathrm{MH}, \mathrm{CH}$ atau $\mathrm{OH}$.

3) Dari grafik batas cair (LL) dan indeks plastisitas (PI) (Gambar 2 Grafik Klasifikasi Tanah Berdasarkan Sistem Klasifikasi USCS) diperoleh LL dan PL yang diplot berada di dalam garis $\mathrm{OH}$ dan $\mathrm{MH}$, maka tanah tersebut termasuk kelompok MH.

4) Secara visual, tanah berwarna coklat-hitam dan bercampur dengan sedikit pasir, Kelompok MH merupakan kelompok Lanau organik atau pasir halus diatomae, atau lanau diatomae, lanau yang elastis. 


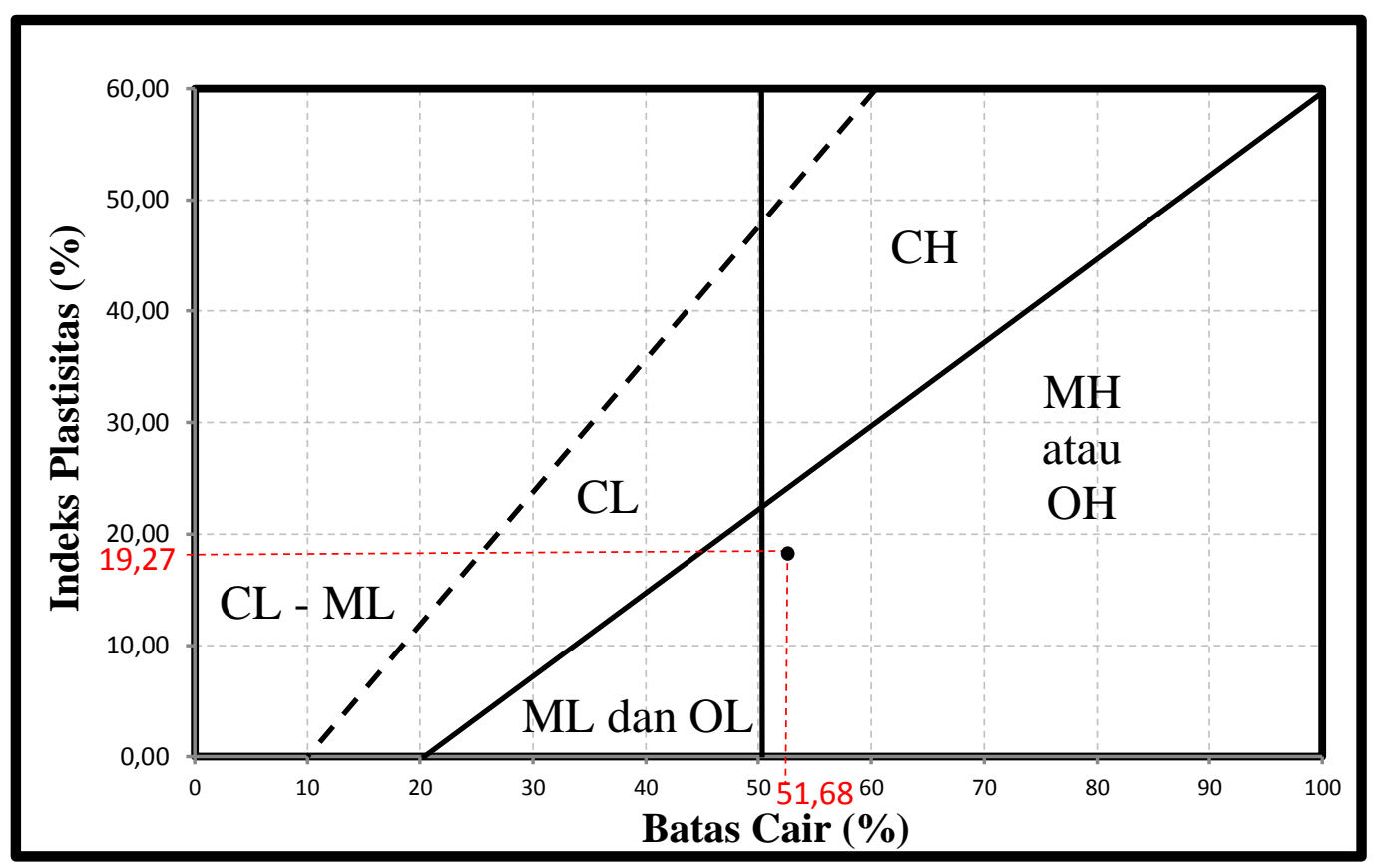

Gambar 2. Grafik Klasifikasi Tanah Sistem Klasifikasi USCS

\section{Analisis Stabilitas Lereng}

Analisis kestabilan lereng tanpa perkuatan lereng dilakukan pada stabilitas terhadap kelongsoran lereng. Hasil perhitungan dilakukan secara manual dengan metode Fellenius.

\section{Analisis Lereng dengan Metode Fellenius}

Berdasarkan dari data yang diperoleh melalui uji laboratorium, maka didapatkan ilustrasi gambar seperti pada Gambar 3 berikut :

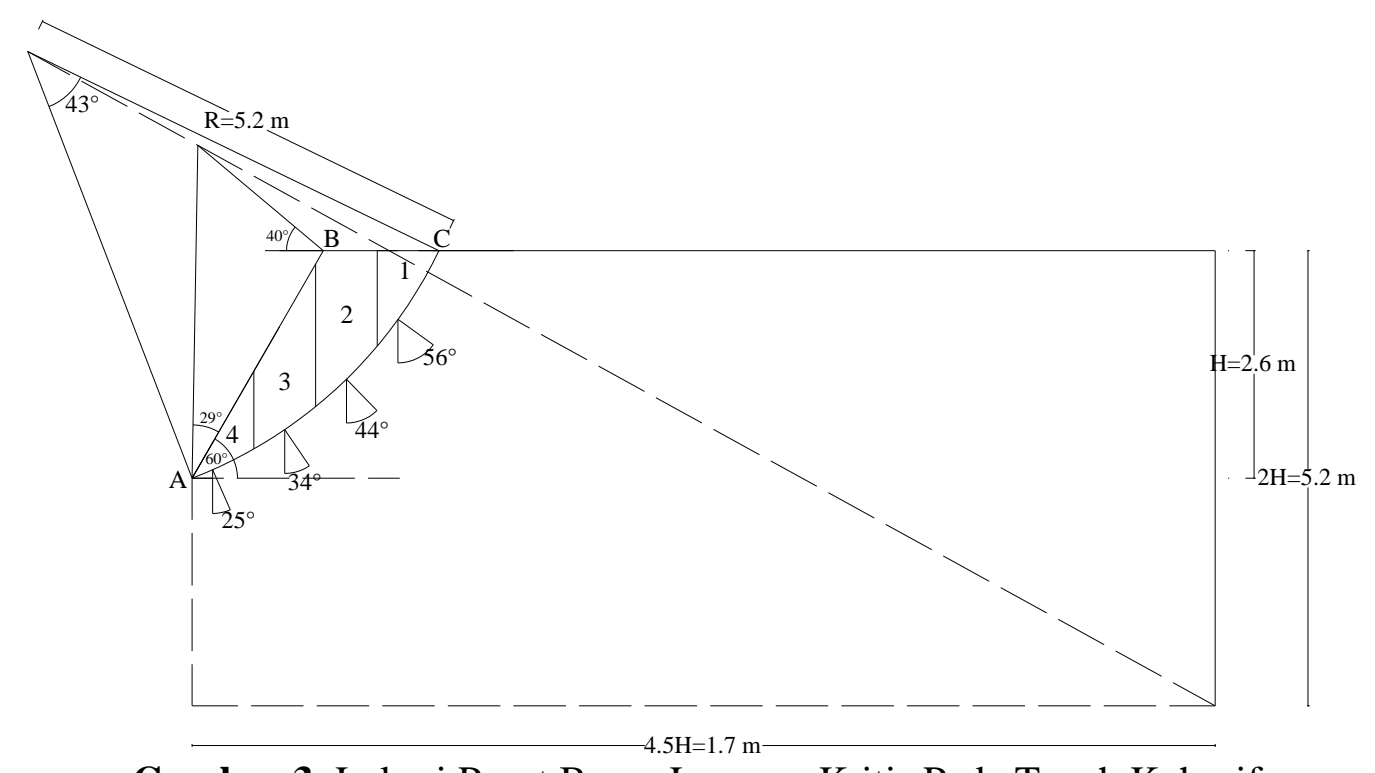

Gambar 3. Lokasi Pusat Busur Longsor Kritis Pada Tanah Kohesif 


\section{Perhitungan manual dengan metode Fellenius}

Untuk lebih detailnya hasil dari perhitungan dapat dilihat pada Tabel

Tabel 2 Perhitungan Metode Fellenius

\begin{tabular}{|c|c|c|c|c|c|c|c|c|c|c|c|c|}
\hline No & $\begin{array}{c}\mathrm{h} \\
(\mathrm{m})\end{array}$ & $\begin{array}{c}\mathrm{b} \\
(\mathrm{m})\end{array}$ & $\begin{array}{c}\text { Luas } \\
(\mathrm{m})\end{array}$ & $\alpha^{\circ}$ & $\operatorname{Sin} \alpha$ & $\operatorname{Cos} \alpha$ & $\begin{array}{c}\text { Berat } \\
\text { Irisan }\end{array}$ & Wsin $\alpha$ & Wcos & U & $\mathrm{I}$ & U.I \\
\hline 1 & 1.2 & 1.2 & 0.7 & 54 & 0.809 & 0.588 & 12.2 & 9.902 & 7.197 & 11.77 & 2.041 & 24.024 \\
\hline 2 & 1.6 & 1.2 & 1.7 & 44 & 0.695 & 0.719 & 28.6 & 19.849 & 20.535 & 15.70 & 1.669 & 26.196 \\
\hline 3 & 1 & 1.2 & 1.6 & 34 & 0.559 & 0.829 & 26.5 & 14.825 & 21.985 & 9.81 & 1.448 & 14.200 \\
\hline 4 & 1 & 1.2 & 0.6 & 24 & 0.407 & 0.913 & 10.2 & 4.151 & 9.313 & 9.81 & 1.314 & 12.894 \\
\hline$\Sigma$ & & & & & & & & 48.727 & 59.029 & & & 77.315 \\
\hline
\end{tabular}

Nilai faktor keamanan terhadap kelongsoran:

$$
\begin{aligned}
\mathrm{F} \quad & =\frac{\sum(\mathrm{c} . \mathrm{L}+\tan \theta \times(\mathrm{W} \cos \alpha)}{\sum \mathrm{W} \sin \alpha} \\
& =\frac{14,22 \times 3,8+0,321 \times(59,029)}{48,727}=1,5>1,2 \ldots . \text { Aman }
\end{aligned}
$$

Untuk kondisi lereng terendam air :

$$
\begin{aligned}
\mathrm{F} & =\frac{\sum(\mathrm{c} . \mathrm{L}+\tan \theta \mathrm{x}(\mathrm{W} \cos \alpha-\mathrm{Ul})}{\sum \mathrm{W} \sin \alpha} \\
& =\frac{14,22 \times 3,8+0,321 \times(59,029-77,315)}{48,727}=0,9<1,2 \ldots . . \text { Tidak aman }
\end{aligned}
$$

Berdasarkan data yang telah diperoleh, perhitungan menggunakan metode Fellenius didapatkan nilai faktor keamanan lereng $=1,5>1,2$ yang berarti aman untuk kondisi lereng tidak terendam air. Sedangkan untuk kondisi lereng terendam air didapatkan nilai faktor keamanan lereng $=0,9<1,2$ yang berarti tidak aman.

\section{1) Perencanaan Dinding Penahan Tanah}

Untuk keperluan perencanaan dinding penahan, diperlukan data tanah di lapangan.

Dalam penelitian ini digunakan data tanah yang terletak di Kota Muara

Teweh, Kabupaten Barito Utara.

Dinding Penahan Tanah Tipe Kantilever

Menentukan dimensi dinding penahan tanah

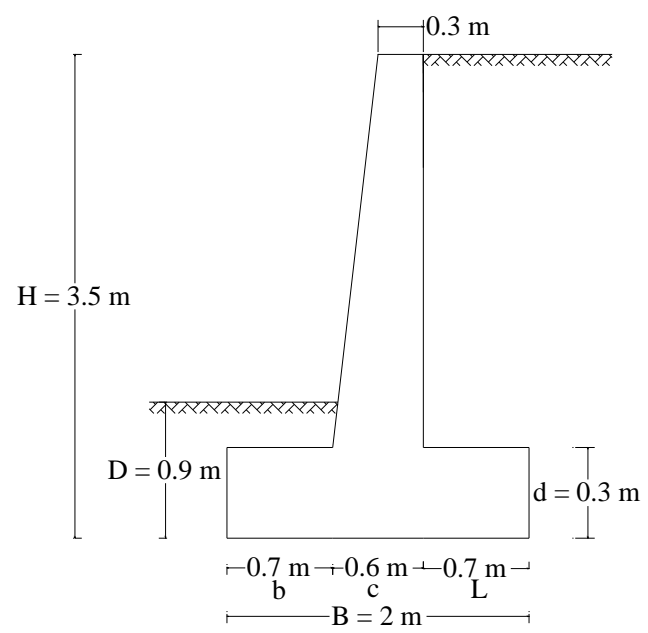

Gambar 4. Dinding penahan tanah kantilever 
Perhitungan Stabilitas Dinding Penahan Tanah Kantilever dengan dimensi :

- $\quad$ Tinggi tembok penahan $(\mathrm{H})=3,5 \mathrm{~m}$

- Untuk lebar a $(\min 0,3 \mathrm{~m}) \quad=0,3 \mathrm{~m}$

- Untuk lebar b $(0,1 \mathrm{H}) \quad=0,7 \mathrm{~m}$

- Untuk lebar c $(0,1 \mathrm{H}) \quad=0,6 \mathrm{~m}$

- Untuk Lebar L $\quad=0,7 \mathrm{~m}$

- Untuk tinggi d $(0,1 \mathrm{H})=0,3 \mathrm{~m}$

- Untuk tinggi D $\quad=0,9 \mathrm{~m}$

\section{Menghitung Tekanan Tanah}

Diketahui data tanah sebagai berikut:

- $\operatorname{Berat}$ isi tanah $(\gamma) \quad=17 \mathrm{kN} / \mathrm{m}^{3}$

- Sudut geser $(\varphi) \quad=17,82^{\circ}$

- $\operatorname{Kohesi}(\mathrm{c}) \quad=14,22 \mathrm{kN} / \mathrm{m}^{2}$

Koefisien tekanan tanah :

Koefisien tanah aktif

$K a=\operatorname{Tan}^{2}\left(45-\frac{\emptyset}{2}\right)=\operatorname{Tan}^{2}\left(45-\frac{17,82}{2}\right)=\operatorname{Tan}^{2} 36,1=0,5$

Koefisien tanah pasif

$K \mathrm{p}=\operatorname{Tan}^{2}\left(45+\frac{\emptyset}{2}\right)=\operatorname{Tan}^{2}\left(45+\frac{17,82}{2}\right)=\operatorname{Tan}^{2} 53,9=1,9$

Tekanan tanah aktif

$$
\begin{aligned}
\mathrm{P}_{a_{1}} & =\frac{1}{2} \gamma \mathrm{H}^{2} \times \mathrm{K}_{\mathrm{a}} \\
& =\frac{1}{2} \times 17 \times 3,5^{2} \times 0,5=52,06 \mathrm{kN} / \mathrm{m}^{2} \\
\mathrm{P}_{a_{2}} & =2 \mathrm{c} \sqrt{\mathrm{Ka}} \times \mathrm{H} \\
& =2 \times 14,22 \sqrt{0,5} \times 3,5=37,62 \mathrm{kN} / \mathrm{m}^{2} \\
\sum_{P_{a}} & =\mathrm{P}_{a_{1}}-\mathrm{P}_{a_{2}} \\
& =14,44 \mathrm{kN} / \mathrm{m}^{2} \\
M_{a} \quad=\mathrm{P}_{a_{1}} \times \frac{H}{3}-\mathrm{P}_{a_{2}} \times \frac{H}{2} & \quad=52,06 \times \frac{3,5}{3}-37,62 \times \frac{3,5}{2}=25,27 \mathrm{kN} / \mathrm{m}^{2}
\end{aligned}
$$

Menghitung gaya vertikal dan momen yang bekerja

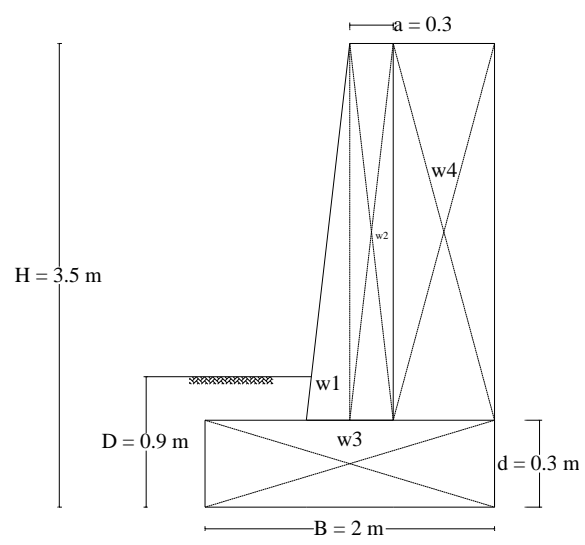

Gambar 5. Gaya dan momen yang bekerja pada dinding penahan Tanah 
Tabel 3. Gaya vertikal dan momen yang bekerja

\begin{tabular}{|c|c|c|c|}
\hline Segmen & $\begin{array}{c}\text { Berat/Satuan Panjang } \\
(\mathrm{kN} / \mathrm{m})\end{array}$ & $\begin{array}{c}\text { Lengan Momen } \\
\text { Terhadap Titik O (m) }\end{array}$ & $\begin{array}{c}\text { Momen Terhadap } \\
\text { Titik O (m) }\end{array}$ \\
\hline 1 & $0,3 \times \frac{3,2}{2} \times 1 \times 24=11,52$ & 0,9 & 10,368 \\
\hline 2 & $0,3 \times 3,2 \times 1 \times 24=23,04$ & 1,15 & 26,496 \\
\hline 3 & $0,3 \times 2,1 \times 1 \times 24=15,12$ & 1 & 15,12 \\
\hline 4 & $3,2 \times 0,7 \times 1 \times 17=38,08$ & 1,65 & 62,832 \\
\hline$\sum_{\mathrm{v}}$ & 87,76 & $\sum_{\mathrm{Mp}}$ & 114,816 \\
\hline
\end{tabular}

Sumber : Hasil olahan

Catatan: $\gamma$ tanah $: 17 \mathrm{kN} / \mathrm{m} 3 ; \gamma$ beton : $24 \mathrm{kN} / \mathrm{m} 3$

Stabilitas terhadap Gaya Guling

$\mathrm{Ph}=14,44 \mathrm{kN} / \mathrm{m}^{2}$

$\mathrm{M}_{a}=25,27 \mathrm{kN} / \mathrm{m}^{2}$

$\mathrm{F}_{\text {guling }}=\frac{\sum_{M_{p}}}{\sum_{M_{a}}}=\frac{114,816}{25,27}=4,54 \geq 1,5 \ldots \ldots . \mathrm{OK}$

\section{Stabilitas terhadap Gaya Geser}

$$
\begin{aligned}
\mathrm{F} & =\sum \mathrm{V} \times \tan (\varnothing) \\
& =87,76 \times \tan 17,82^{\circ} \\
& =28,17 \mathrm{kN} / \mathrm{m}^{2} \\
\mathrm{~F}_{\text {geser }} & =\frac{F}{P_{h}}=\frac{28,17}{14,44}=1,95 \geq 1,5
\end{aligned}
$$

Menghitung stabilitas terhadap kapasitas dukung tanah eksentrisitas (e)

\section{Penurunan :}

$$
\begin{aligned}
\sum_{\mathrm{M}} & =\mathrm{M}_{\mathrm{p}}-\mathrm{M}_{\mathrm{a}} \\
& =114,816-25,27 \\
& =89,55 \mathrm{kN} / \mathrm{m}^{2} \\
\mathrm{x} \quad & =\frac{\sum \mathrm{M}}{V}=\frac{89,55}{87,76}=1,02 \\
\mathrm{e}=\mathrm{x} & -\frac{\mathrm{B}}{2}=0,02 \leq \frac{\mathrm{B}}{6}=0,3 \ldots \ldots . \mathrm{OK}
\end{aligned}
$$

$\mathrm{q}_{\max }$ dan $\mathrm{q}_{\min }$ :

$\mathrm{q}_{\max }=\frac{\sum \mathrm{V}}{\mathrm{B}}\left(1+\frac{6 e}{B}\right)=\frac{87,76}{2}\left(1+\frac{6 x 0,02}{2}\right)=43,94 \mathrm{kN} / \mathrm{m}^{2}<\mathrm{q}_{\mathrm{ijin}}=217 \mathrm{kN} / \mathrm{m}^{2}$

$\mathrm{q}_{\text {min }}=\frac{\sum \mathrm{V}}{\mathrm{B}}\left(1-\frac{6 e}{B}\right)=\frac{87,76}{2}\left(1-\frac{6 \times 0,02}{2}\right)=43,82 \mathrm{kN} / \mathrm{m}^{2}<\mathrm{q}_{\mathrm{ijin}}=217 \mathrm{kN} / \mathrm{m}^{2}$

\section{Kapasitas daya dukung tanah}

Untuk perhitungan daya dukung tanah menggunakan Metode Terzaghi berdasarkan ketentuan rumus :

$\mathrm{q}_{\mathrm{u}}=\mathrm{c} \times \mathrm{N}_{\mathrm{c}}+\mathrm{q}_{\mathrm{o}} \times \mathrm{N}_{\mathrm{q}}+0,5 \times \mathrm{B} \times \gamma \times \mathrm{N}_{\gamma}$ 
dimana :

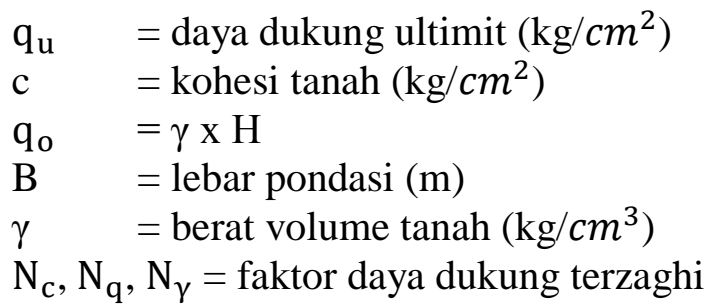

Berdasarkan tabel daya dukung tanah (terzaghi) dengan $\psi^{\circ}=17,82^{\circ}$

$\mathrm{N}_{\mathrm{c}}=14,7, \mathrm{~N}_{\mathrm{q}}=6,2, \mathrm{~N}_{\gamma}=4,3$

sehingga :

$\mathrm{q}_{\mathrm{u}}=\mathrm{c} \times \mathrm{N}_{\mathrm{c}}+\mathrm{q}_{\mathrm{o}} \times \mathrm{N}_{\mathrm{q}}+0,5 \times \mathrm{B} \times \gamma \times \mathrm{N}_{\gamma}$

$=14,22 \times 14,7+59,5 \times 6,2+0,5 \times 2 \times 17 \times 4,3$

$=651,034 \mathrm{kN} / \mathrm{m}^{2}$

$\mathrm{q}_{\mathrm{ijin}}=\frac{\mathrm{q}_{\mathrm{u}}}{3}=217 \mathrm{kN} / \mathrm{m}^{2}$

Berdasarkan perhitungan di atas diketahui bahwa dimensi dinding penahan tanah aman terhadap Faktor Guling dan Geser.

\section{PENUTUP}

\section{Kesimpulan}

Berdasarkan hasil pengujian yang dilakukan oleh PT. CEMARA GEO ENGINEERING dan analisis data yang telah dilakukan terhadap tanah di Kota Muara Teweh Kabupaten Barito Utara maka diperoleh kesimpulan sebagai berikut:

1. Hasil pengujian sifat - sifat fisik tanah di dapat nilai, kadar air $(\mathrm{w})=27,50 \%$; berat isi kering $(\gamma)=1,34 \mathrm{~g} / \mathrm{cm}^{3}$; berat jenis $(\mathrm{Gs})=2,342 \mathrm{~g} / \mathrm{cm}^{3}$; batas-batas Atterberg yaitu $L L=51,68 \% ; P L=32,41 \% ; P I=19,27 \%$; analisis saringan persentase lolos saringan No $200 \mathrm{~mm}=16,65 \%$. Menurut AASHTO tanah diklasifikasikan tanah lanau berpasir, dalam kelompok A-2-7, dan menurut USCS tanah di klasifikasikan tanah Lanau organik atau pasir halus diatomae, atau lanau diatomae, lanau yang elastis, dan secara visual tanah berwarna coklat-hitam dan bercampur dengan sedikit pasir, maka tanah tersebut termasuk dalam kelompok MH.

2. Hasil analisis stabilitas lereng :

a. Nilai faktor keamanan lereng $=1,5>1,2$ yang berarti aman untuk kondisi lereng tidak terendam air.

b. Nilai faktor keamanan lereng $=0,9<1,2$ yang berarti tidak aman untuk kondisi lereng terendam air.

3. Hasil analisis dinding penahan tanah tipe Kantilever untuk stabilitas terhadap gaya guling $=4,54>1,5$; untuk stabilitas terhadap gaya geser $=1,95>1,5$; untuk stabilitas terhadap daya dukung tanah $=651,034 \mathrm{kN} / \mathrm{m}^{2}$. Hasil perhitungan analisis dinding penahan tanah tipe kantilever menyatakan aman terhadap gaya guling dan geser.

\section{Saran}

Berdasarkan hasil dari penelitian dan analisis data yang dilakukan, maka disarankan hal-hal sebagai berikut : 
a) Perlu dievaluasi terhadap kekuatan tanahnya maupun kekuatan dinding penahan tanahnya.

b) Supaya tercapainya angka keamanan (F) terhadap pergeseran dengan memperbesar alas pondasi atau dibuat konstruksi pengunci.

c) Supaya tercapainya angka keamanan (F) terhadap penggulingan dengan memperpanjang kaki atau tumit.

d) Untuk perhitungan dan analisa dinding penahan tanah sebaiknya menggunakan program bantu untuk mempermudah mendapatkan hasil perhitungan yang akurat.

\section{DAFTAR PUSTAKA}

Bowles, J E. 1984. Sifat-Sifat Fisis dan Geoteknis Tanah (Mekanika Tanah), Edisi Kedua. Erlangga. Jakarta.

Bowles, J E. 1991. Sifat-sifat Fisis Tanah dan Geoteknis Tanah. Erlangga. Jakarta.

Craig, R. F. 1987. Soil Mechaanic 4th Edition. Van Nostroad Reinhol Co. Ltd. Diterjemahkan oleh Budi Susilo Supandji, 1989.Mekanika Tanah Edisi Keempat. Erlangga. Jakarta.

Das, Braja M. 1995. Mekanika Tanah Jilid I (Prinsip-prinsip Rekayasa Geoteknis). Erlangga. Jakarta.

Grim, R. E. (1976), Applied Clay Mineralogy, MeGraw-Hill Book Company, New York.

Hardiyatmo, H C. 1992. Mekanika Tanah 1. PT. Gramedia Pustaka Utama. Jakarta.

Hardiyatmo, H C. 2002. Mekanika Tanah I (edisi III). Gadjah Mada University Press. Yogyakarta.

Husein Husman, 1987. Social Relationship in Government development infrastructure, Jakarta : Bumiaksara.

Mitchell, J. K. (1976), Fundamentals of soil Behavior, john wily and son, Inc, New York.

Panduan Praktikum Mekanika Tanah II. 2018. Fakultas Teknik Universitas Palangka Raya.

Terzaghi, Karl and Peck, B Ralph, "Soil Mechanics in Engineering Practice, Second Edition",

Wesley, L. D. 1973. Mekanika Tanah. Jakarta : Badan Penerbit Pustaka Umum. 